\title{
Technical Progress Report for the Gas Storage Technology Consortium
}

\author{
Quarterly Report for the Period \\ 9/30/2003 - 12/31/2003
}

\section{By}

Dr. Robert W. Watson

Principal Investigator

\section{Work Performed Under DOE Cooperative Agreement DE-FC26-03NT41779}

\author{
Report Issued __ April 23, 2004 \\ Submitting Organization \\ The Pennsylvania State University \\ The Energy Institute \\ C211 Coal Utilization Lab \\ University Park, PA 16802
}




\section{DISCLAIMER}

This report was prepared as an account of work sponsored by an agency of the United States Government. Neither the United States Government nor any agency thereof, nor any of their employees, makes any warranty, express or implied, or assumes any legal liability or responsibility for the accuracy, completeness, or usefulness of any information, apparatus, product, or process disclosed, or represents that its use would not infringe privately owned rights. Reference herein to any specific commercial product, process, or service by trade name, trademark, manufacturer, or otherwise does not necessarily constitute or imply its endorsement, recommendation, or favoring by the United States Government or any agency thereof. The views and opinions of authors expressed herein do not necessarily state or reflect those of the United States Government or any agency thereof. 


\section{ABSTRACT}

Gas storage is a critical element in the natural gas industry. Producers, transmission and distribution companies, marketers, and end users all benefit directly from the load balancing function of storage. The unbundling process has fundamentally changed the way storage is used and valued. As an unbundled service, the value of storage is being recovered at rates that reflect its value. Moreover, the marketplace has differentiated between various types of storage services, and has increasingly rewarded flexibility, safety, and reliability. The size of the natural gas market has increased and is projected to continue to increase towards 30 trillion cubic feet (TCF) over the next 10 to 15 years. Much of this increase is projected to come from electric generation, particularly peaking units. Gas storage, particularly the flexible services that are most suited to electric loads, is critical in meeting the needs of these new markets.

In order to address the gas storage needs of the natural gas industry, an industrydriven consortium was created - the Gas Storage Technology Consortium (GSTC). The objective of the GSTC is to provide a means to accomplish industry-driven research and development designed to enhance operational flexibility and deliverability of the Nation's gas storage system, and provide a cost effective, safe, and reliable supply of natural gas to meet domestic demand. To accomplish this objective, the project is divided into three phases that are managed and directed by the GSTC Coordinator. Base funding for the consortium is provided by the U.S. Department of Energy (DOE). In addition, funding is anticipated from the Gas Technology Institute (GTI).

The first phase, Phase 1A, was initiated on September 30, 2003, and is scheduled for completion on March 31, 2004. Phase 1A of the project includes the creation of the GSTC structure, development of constitution (by-laws) for the consortium, and development and refinement of a technical approach (work plan) for deliverability enhancement and reservoir management. This report deals with the first 3-months of the project and encompasses the period September 30, 2003, through December 31, 2003. During this 3-month period, the first meeting of individuals representing the storage industry, universities and the Department of energy was held. The purpose of this meeting was to initiate the dialogue necessary to for the creation and adoption of a constitution that would be used to govern the activities of the consortium. 


\section{TABLE OF CONTENTS}

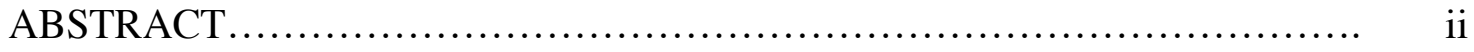

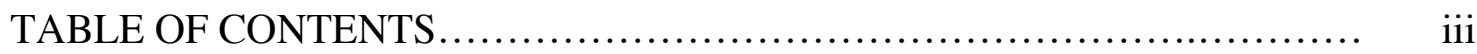

Executive Summary................................................ 1

Experimental........................................................... 2

Results and Discussions............................................... 2

Conclusions....................................................... 3

References............................................................ 3 


\section{Executive Summary}

Gas storage is a critical element in the natural gas industry. Producers, transmission and distribution companies, marketers, and end users all benefit directly from the load balancing function of storage. The unbundling process has fundamentally changed the way storage is used and valued. As an unbundled service, the value of storage is being recovered at rates that reflect its value. Moreover, the marketplace has differentiated between various types of storage services, and has increasingly rewarded flexibility, safety, and reliability. The size of the natural gas market has increased and is projected to continue to increase towards 30 trillion cubic feet (TCF) over the next 10 to 15 years. Much of this increase is projected to come from electric generation, particularly peaking units. Gas storage, particularly the flexible services that are most suited to electric loads, is critical in meeting the needs of these new markets.

In order to address the gas storage needs of the natural gas industry, an industrydriven consortium was created - the Gas Storage Technology Consortium (GSTC). The objective of the GSTC is to provide a means to accomplish industry-driven research and development designed to enhance operational flexibility and deliverability of the Nation's gas storage system, and provide a cost effective, safe, and reliable supply of natural gas to meet domestic demand. To accomplish this objective, the project is divided into three phases that are managed and directed by the GSTC Coordinator. Base funding for the consortium is provided by the U.S. Department of Energy (DOE). In addition, funding is anticipated from the Gas Technology Institute (GTI).

The first phase, Phase 1A, was initiated on September 30, 2003, and is scheduled for completion on March 31, 2004. Phase 1A of the project includes the creation of the GSTC structure, development of constitution (by-laws) for the consortium, and development and refinement of a technical approach (work plan) for deliverability enhancement and reservoir management. This report deals with the first 3-months of the project and encompasses the period September 30, 2003, through December 31, 2003. During this 3-month, the first meeting of individuals representing the storage industry, academia and the U.S. Department of Energy (DOE) was held at the Pennsylvania State 
University (Penn State) in University Park, Pennsylvania. The meeting was held on December 4, 2003. At this meeting, drafts of the constitution and by-laws were discussed in detail and the dialogue to create a workable consortium initiated.

\section{Experimental}

This project is in its initial stages therefore there are no experimental results available at this time.

\section{$\underline{\text { Results and Discussion }}$}

As stated in the Executive Summary, the first order of business for this project was the scheduling of a meeting at Penn State. The purpose of this meeting was to initiate the dialogue necessary for the creation and adoption of a constitution that would be used to govern the activities of the consortium. This meeting was held on December 4, 2003, on the campus of the Pennsylvania State University. In attendance were 28representatives of academia, the DOE and the storage industry. Drafts of the constitution and by-laws were presented to those in attendance. These document drafts were prepared using as guidelines the by-laws and constitutions of the DOE funded Consortium for Premium Carbon Products from Coal (CPCPC) and Stripper Well Consortium (SWC). The CPCPC and SWC have been successful vehicles for the funding of applied research and the extension of their model to the GSTC was considered appropriate.

The meeting demonstrated that much work needed to be done to develop a workable constitution for the governance of the GSTC. Moreover, it was agreed that bylaws were unnecessary and governance of the consortium could be accomplished through a constitution. A second meeting to continue the dialogue was tentatively scheduled for late January 2004 or early February in Atlanta, Georgia. Moreover, efforts would be made to schedule this meeting so that it would coincide with the Pipeline Research Council International (PRCI) storage committee meeting that had been scheduled at approximately the same time in Atlanta.

Moreover, given that representatives of academia and industry who are involved in natural gas storage research would be in attendance at the Atlanta Meeting for either 
the Gas Storage Technology Consortium or the PRCI storage committee meetings, the DOE offered to sponsor a Storage Consortium Workshop prior to these meetings. The purpose of this workshop would be to identify the research and technology needs of the industry and to use these results to steer the research of the consortium for the near-term.

\section{Conclusions}

The work necessary to bring the consortium from the stage of being a concept to one of a reality was begun during the first quarter of this project. To this end, the dialogue among industry, academia and the DOE was begun. A meeting where the interested parties discussed the proposed constitution was held and additional meetings to continue this dialogue planned.

\section{References}

There are no references at this time for this report. 